\title{
Indian Marine Pharmacology: A Sneak Peek Into the Ecosystem
}

\author{
SRIPATHI RAO KULKARNI and MADHU DIKSHIT* \\ Central Drug Research Institute, Lucknow, Uttar Pradesh 226 031, India
}

(Received on 09 September 2017; Accepted on 16 October 2017)

\begin{abstract}
This article tries to sift and collate the current status of the Marine Pharmacology with specific reference to the Indian contributions. The rich and diverse marine flora and fauna along the Indian coastline offers a wealth of resources to explore and exploit towards the benefit of the human health ranging from antioxidants/anti-inflammatory to antibacterials/ antimicrobials to anticancer entities and further to those that affect metabolic syndromes. It specifically outlines the range of chemical entities and/or their derivatives that are explored from the marine ecosystems towards various pharmacological indications.
\end{abstract}

Keywords: Marine Pharmacology; Marine Flora and Fauna; Ecosystems; Indian Research

\section{Introduction}

Marine biodiversity harbours variety of life in the sea, encompassing variation at levels of complexity from within species to across ecosystems. India is among one of the 12 mega biodiversity countries and 25 hot-spots possessing the highly enriched and highly endangered eco-regions of the world. India is the only country among Asian countries that has a long recorded inventory of coastal and marine biodiversity dating back to at least two centuries, having a coastline of about $7517 \mathrm{~km}, 5423 \mathrm{~km}$ along the mainland and $2094 \mathrm{~km}$ in the Andaman and Nicobar Islands and Lakshadweep Islands. It has in its realm around 844 species of seaweeds distributed among 217 genera, 486 species of sponges and 218 species of hard corals. Despite having such abundant resources only a select few marine organism are known for their usefulness in public domain (Mittermeier et al.,2000; Demunshi and Chug, 2009).

Oceans account for more than $80 \%$ of diverse plant and animal species in the world. Marine organisms such as sponges, tunicates, fishes, soft corals, nudibranchs, sea hares, opisthobranch molluscs, echinoderms, bryozoans, prawns, shells, sea slugs, and marine microorganisms are the main sources of bioactive materials (viz., oils and cosmetics) (Donia and Hamann 2003).

Indian coastline spreading for over $8000 \mathrm{~km}$ is interspersed with varied clusters of marine habitats like inter-tidal rocky, muddy and sandy shores, coral reefs, and mangrove forests. In spite of having such abundant resources at its disposal the potential of Indian marine resources seems untapped in terms of new drug discovery or biotechnological advancement undertakings. Institutes such as National Institute of Oceanology, Goa; Central Drug Research Institute, Lucknow; Bose Institute, Kolkata; Central Institute of Fisheries Education, Mumbai; Regional Research Laboratory, Bhubaneswar of Council for Scientific and Industrial Research are currently involved in drug development programmes from marine sources. Various research institutes, academia and pharmaceutical industry are recognising and collaborating to tap the potential of our marine resources (Thakur et al., 2005).

Considering the abundance and potential for large scale production there is a need to review marine pharmacology for the development of new drug moiety. At present, the pharmaceutical industry is working towards phytochemical screening and isolation of novel molecules with unreported pharmacological properties that can be exploited for 
the development of new therapeutic agents and further commercialization. This review has largely focused on different classes of marine drugs currently in use and at different stages of trials for approval and marketing in future. The review has also tried to delve into the challenges and future strategies for drug development from marine sources (Malve, 2016).

On the basis of assignee analysis of the marine based patents in India CSIR has emerged as the leader in terms of patents filed in marine biodiversity (Table 1). Patent analysis also indicates a gradual rise in the number of patents filed relating to marine biodiversity. This indicates a paradigm shift of the scientific community to exploit the vast untapped resources of the ocean flora and fauna (Table 2). The major marine sources identified according to patent data and scientific publications are mangrove, marine actinomycetes and sediment, fish, marine bacteria, marine plants, marine sponge and marine algae (Table $3)$.
Marine pharmacology can be classified on the basis of source of the candidate drug (Murti and Agarwal, 2010)

- Genetically engineered marine organisms

- Manufacture of pharmaceuticals and nutraceuticals of marine origin

- Chemicals produced by or found in marine organisms shown to have a wide variety of applications as pharmaceuticals (Table 4).

Patent trends in India have indicated that main focus of research has been extraction i.e. highest number of patents has been filed for method of extraction, followed by isolation. Only one formulation based patent from marine source has been reported, indicating this area of research virtually untapped. The scientific publication analysis also gives a similar result whereby main focus is on extraction and isolation (Table 5).
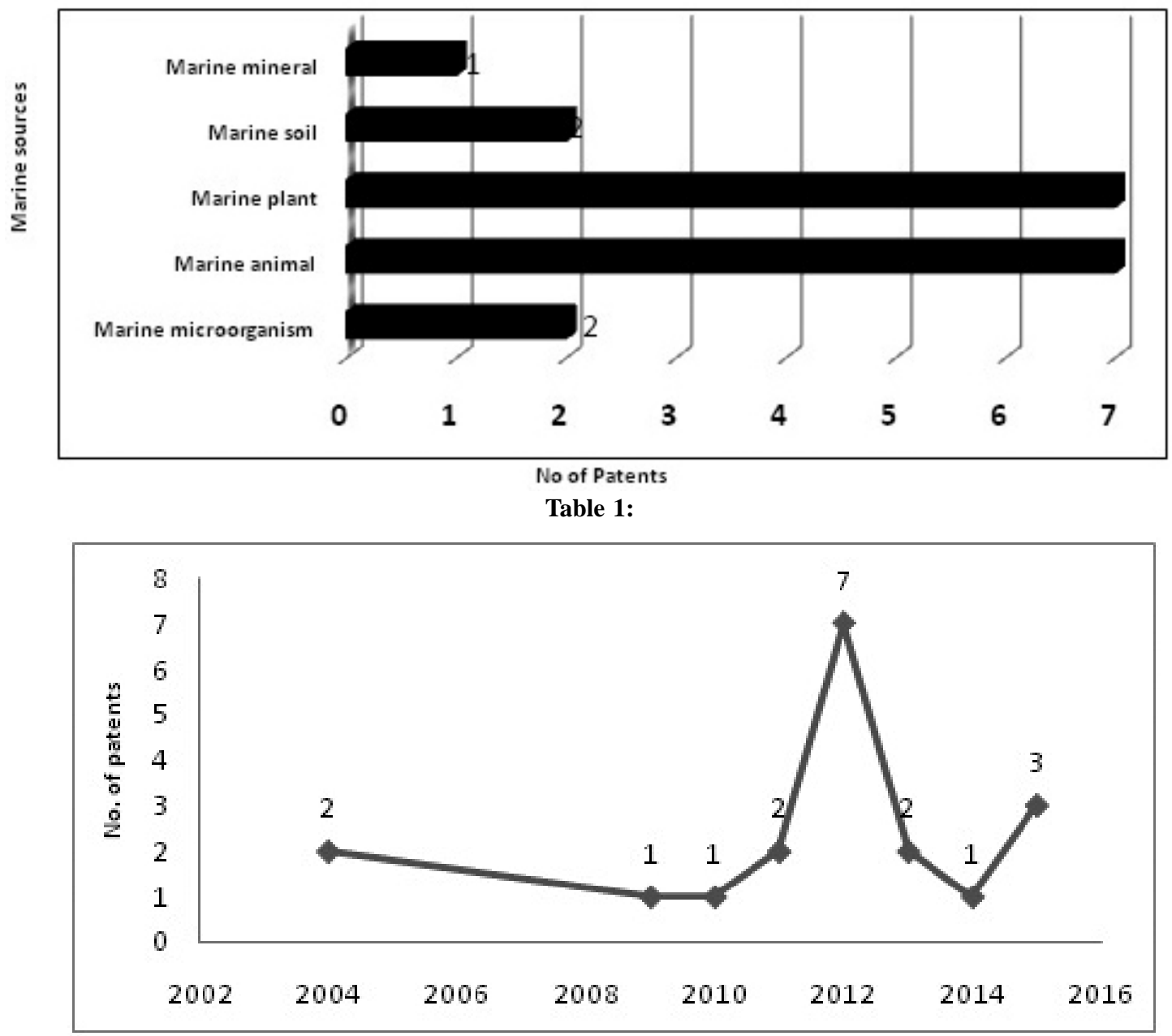

Table 2: 


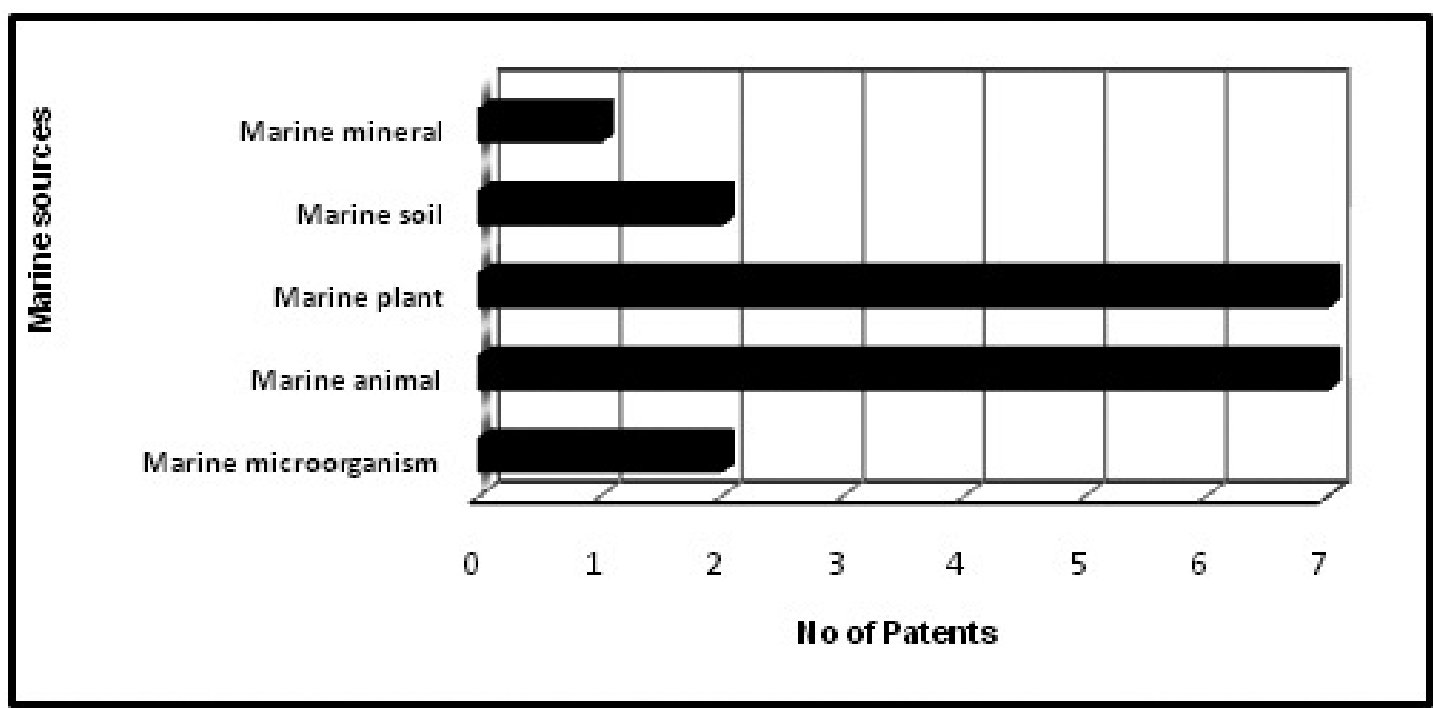

Table 3A:

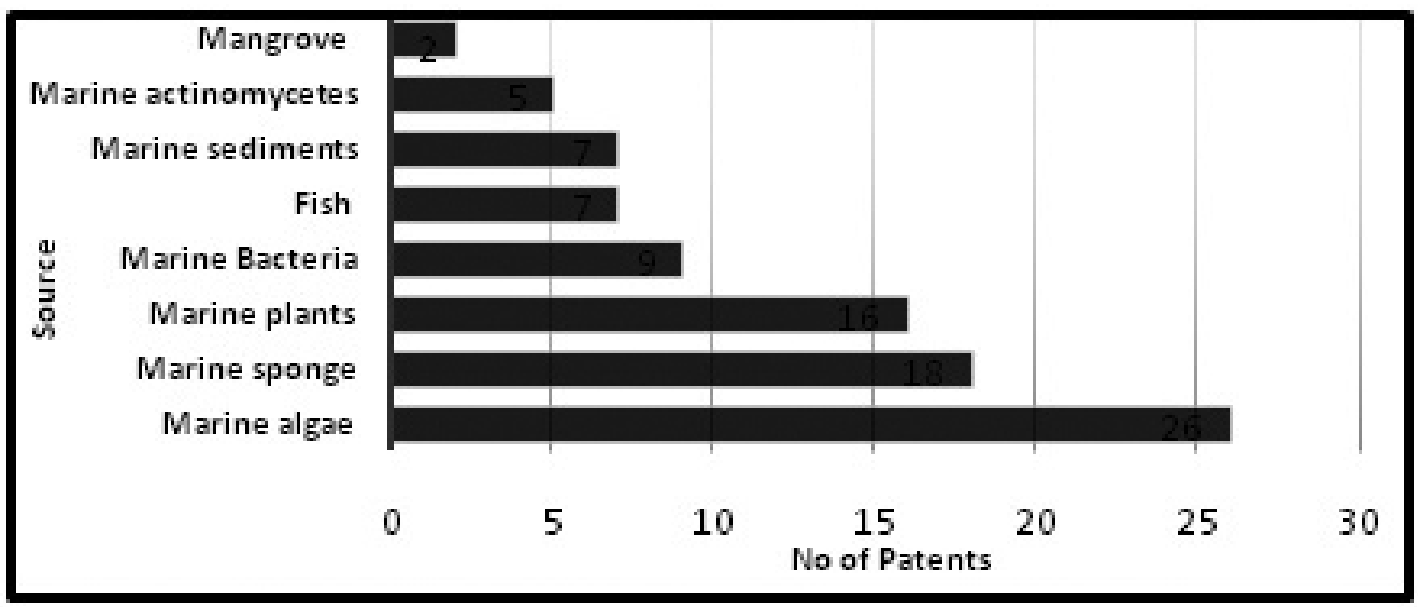

Table 3B:

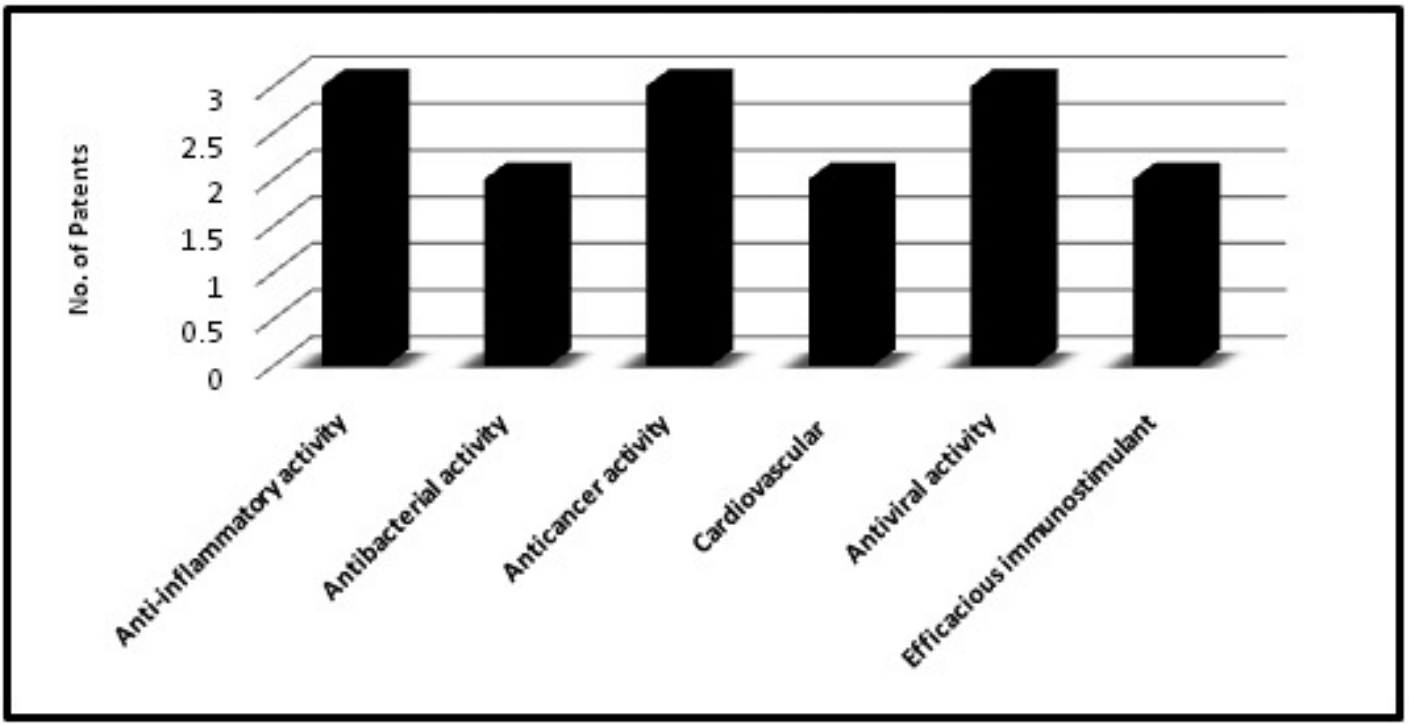

Table 4: 


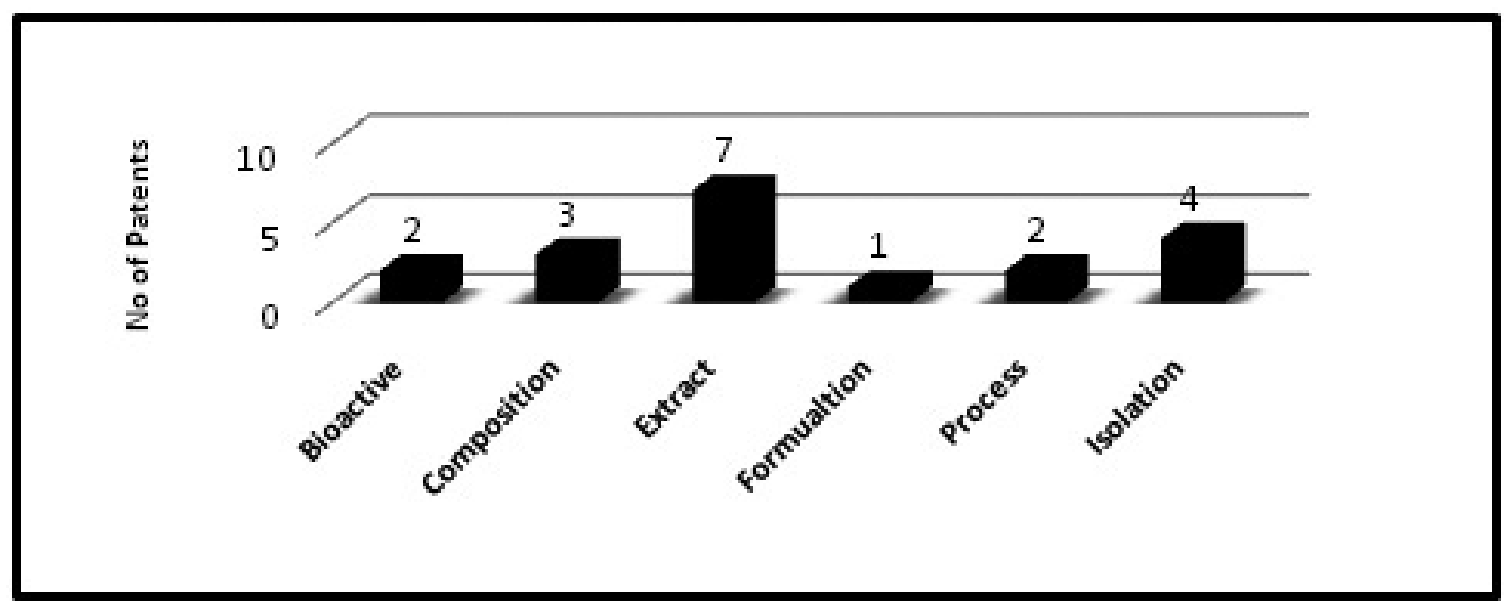

Table 5A:

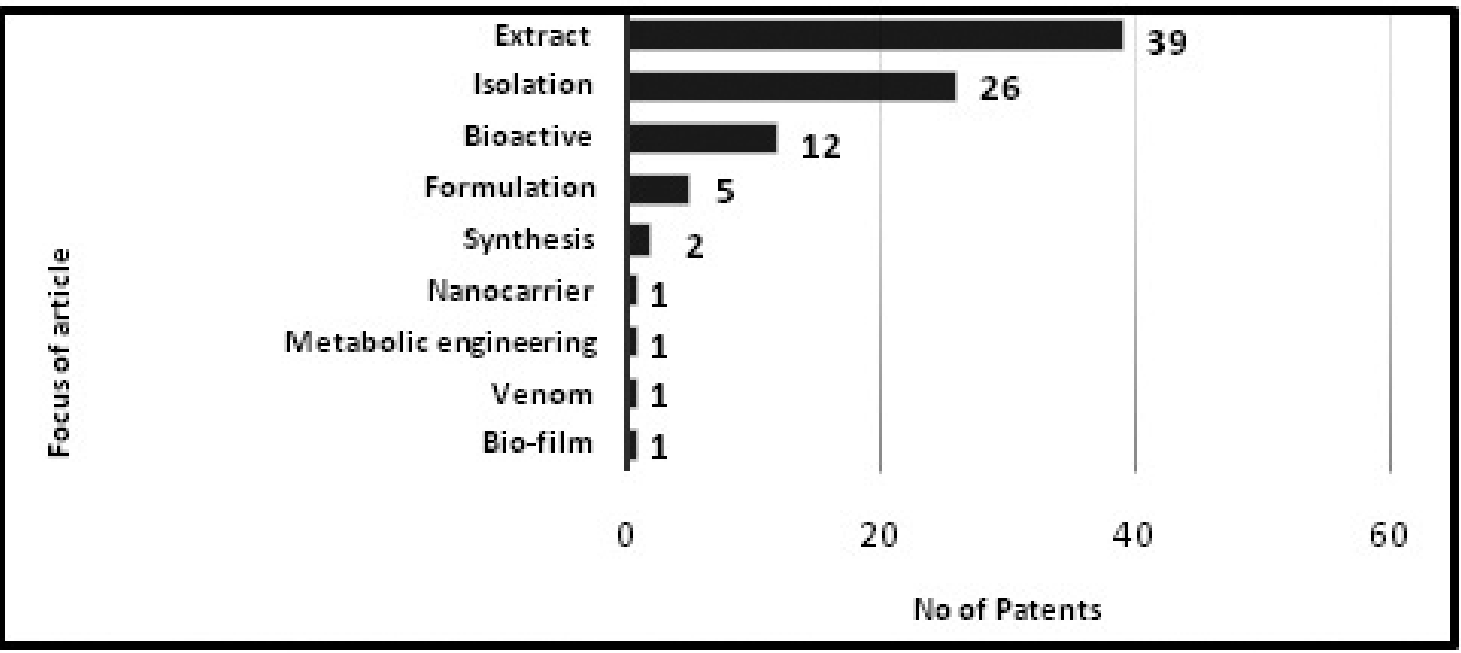

Table 5B:

Marine drugs can be broadly classified based on their actions as follows:

\section{Anti-Inflammatory/Antioxidant}

Two new chromenyl derivatives, characterized as 7(2'-ethyl-1'-hydroxynonan-2'-yl)-6,7,8,8a-tetrahydro$3 \mathrm{H}$-isochromen-1-(5H)-one (Fig. 1) and 6(1)-(3-((E)3(1b)-(furan-2'-yl)-prop-3(1b)-en-3(1)-yl)-4a,5,6,8atetrahydro-8-methyl-2H-chromen-6-yl)-ethyl-5'"-

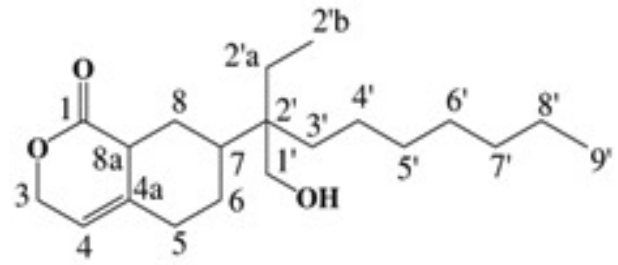

Fig. 1: methyl-hexanoate (Fig. 2) isolated from ethyl acetatemethanol extract of yellow-foot bivalve clam, Paphia malabarica exhibited considerable radical scavenging activities with alpha-tocopherol. The anti-5lipoxygenase activity of the two compounds was significantly more than ibuprofen indicating their potential as anti-inflammatory compounds (Joy and Chakraborty, 2017).

Marineactinomycetes identified as Streptomyces sparsus upon analysis revealed the presence of<smiles>CC(=Cc1ccco1)C1=CC2CC(CCOC(=O)[CH]CCC(C)(C)C)C=C(C)C2OC1</smiles>

Fig. 2: 
tryptophan dehydrobutyrine-diketo-piperazine, maculosin, 7-o-demethyl albocycline, albocycline M2, and 7-o-demethoxy-7-oxo albocycline in a negative ion mode. the spectroscopical analysis showed various compounds like dotriacontane, tetracosane 11-decyl, diheptyl phthalate, 1-hexadecanesulfonyl chloride, L-alanyl-L-tryptophan, phthalic acid ethyl pentyl ester, 4-trifluoroacetoxyhexadecane, and $1 \mathrm{H}$-imidazole 4,5dihydro-2,4 dimethyl. Indicating that ethyl acetate extract of Streptomyces sparsus VSM-30 may have antibacterial, antifungal, and antioxidant activities (Managamuri et al., 2017).

Two novel sterols (22E)-24(1), 24(2)methyldihomocholest-5, 22-dien-3-ol and 23-gemdimethylcholesta-5-en-3-ol obtained from the southwest coast of Arabian Sea ,showing anti-inflammatory potential against cyclooxygenase-2 and 5-lipoxygenase were isolated from Paphia malabarica. The derivative (22E)-24(1), 24(2)-methyldihomocholest5, 22-dien-3-ol, showed antioxidant and antiinflammatory activity significantly greater than 23gem-dimethylcholesta-5-en-3-ol (Joy et al., 2017).

The Bacterial strain Vibrio Spp. (PIGB 184) isolated from Arabian Sea composed of phenol, 2,4bis(1,1-dimethylethyl) and pyrrolo[1,2-a]pyrazine-1,4dione,hexahydro-3-(2-methylpropyl) showed the production of pigmentary antioxidants (Pawar et al., 2016).

The evaluation of three marine diatoms, Chaetoceros curvisetus, Thalassiosira subtilis and Odontella aurita for antioxidant activity, DPPH radical scavenging activity, nitric oxide radical scavenging activity, hydrogen peroxide radical scavenging activity and ferric reducing power indicated that the methanolic extract of $O$. aurita had the maximum total phenolic content and antioxidant property. Total phenol content, total antioxidant activity, DPPH radical scavenging activity (15.25\%), hydrogen peroxide radical scavenging activity $(54.73 \%)$, Ferric reducing power assay and nitric oxide radical scavenging activity were highest in $C$. curvisetus (32.37\%) (Hemalata et al., 2015).

The pigmented bacteria associated with seaweed possess large number of antioxidant compounds and need to be extracted in large scale for clinical studies and use. A Sargassum associated yellowish brown pigmented bacteria Pseudomonas koreensis
(JX915782) showed more activity when compared to standard antioxidant butylated hydroxytoluene (BHT) against DPPH scavenging. Similarly Serratia rubidaea (JX915783), an associate of Ulva Spp. and Pseudomonas argentinensis (JX915781) an epiphyte of Chaetomorpha media, also showed antioxidant activity. It was concluded by gene sequencing analysis bacteria that have higher antioxidant activity belongs to the class Gammaproteobacteria (Pawar et al., 2015).

Two marine red algae Gelidiella acerosa and Sargassum wightii showed excellent antioxidant and anticholinesterase activity. The comet assay analysing the genotoxic activity showed that PBMC (peripheral blood mononuclear cells) treated with seaweed extracts exhibited less or no damage to cells, thus proving the non-genotoxic nature of the extract (Syad and Kasi, 2014).

Alginic acid isolated from the brown algae Sargassum wightii in type II collagen induced arthritic studies in rat showed Treatment with alginic acid significantly reduced the activities of inflammatory marker enzymes like cycloxygenase-2 (COX-2), lipoxygenase (5-LOX), xanthine oxidase (XO) and myeloperoxidase (MPO) rheumatoid factor (RF), ceruloplasmin and C-reactive protein (CRP). Concentrations of proinflammatory cytokines like IL1 beta, TNF alpha and IL- 6 were lowered on treatment with alginic acid. It also reduced the activities of lysosomal enzymes that manifest the systemic damage during arthritis. Treatment with alginic acid indicated that it reduced extensive bone degradation and synovial hyperplasia associated with arthritis, suggesting that aliginic acid can be used for the treatment of rheumatoid arthritis (Saritha Kumari and Kurup, 2013).

Kappaphycus alvarezii (Doty) a marine alga belonging to order: Gigartinales and family: Solieriaceae grows in southeast coast of India. The antioxidant and antigenotoxic/protective studies indicated that long-term administration of $K$. alvarezii extract had antioxidant potential and provided protection against tissue lipid peroxidation and cell damage, making it useful in the food and pharmaceutical industries (Nagarani and Kumaraguru, 2012).

Sargassum myriocystum a sulphated 
polysaccharide identified as Fucoidan showed potential radical scavenging activity compared to butylated hydroxyl toluene, Fig. 3 (Badrinathan et al., 2012). Mi-64, a high molecular weight protein $(130 \mathrm{kDa})$, obtained from marine polychaete (Mastobranchus indicus) collected from the Indian Sunderban significantly inhibited the overproduction of interleukin1 beta, interleukin- 6 , chemoattractant- 1 , and tumor necrosis factor-alpha and augmented interleukin -10 production. The study indicated the role of Mi-64 as potential antiarthritic agent (Alam et al., 2012).

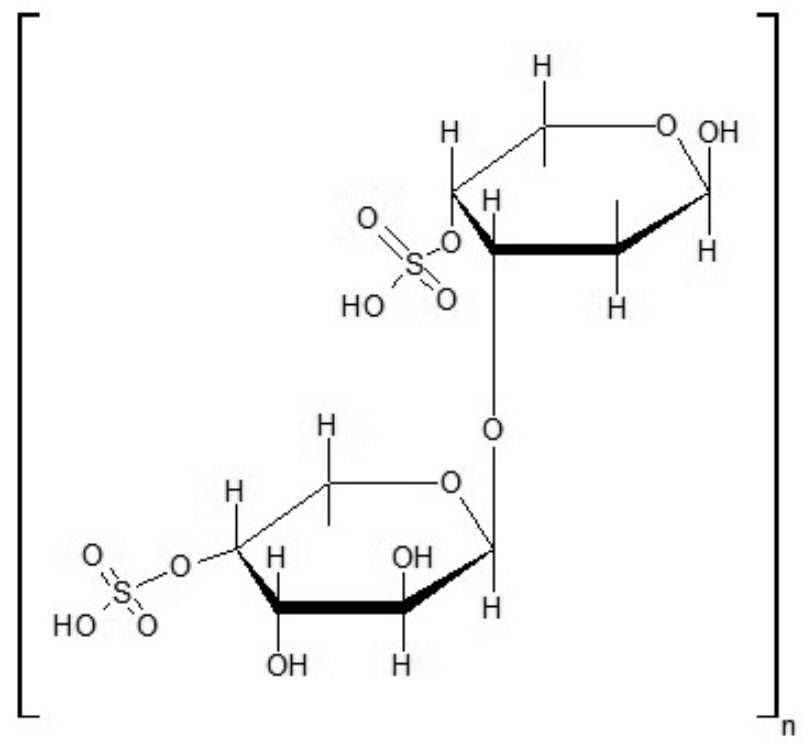

Fig. 3:

\section{Antibacterial/Antimicrobial}

Marine cyanobacterium Oscillatoriaa cuminata NTAPC05 methanol extract was fractionated and a new monogalactosyl diacyl glycerol having palmitoyl (MGDG-palmitoyl), was obtained showing bactericidal property against beta lactamase ESBL-producing bacteria (Ahamed et al., 2017).

The study on marine actinomycetes was found to contain biologically active compounds that control plant diseases. Many extracts showed strong antifungal and antibacterial activity against Erwinia caratovora, Pyriculariae oryzae, Aspergillus niger and Trichoderma (Dhevagi et al., 2017).

The identification of four species of solitary ascidians and four colonial ascidians from Thoothukudi coast showed that extract of extracellular products (ECP) had weak inhibitory activity against test organisms, but the ethyl acetate crude extract of both cell and cell free supernatants exhibited strong inhibitory activity. Eudistoma viride methanolic extract also showed good antagonistic activity against Vibrio cholerae and V. harveyi (Mary et al., 2016).

The diatom Amphora cf. capitellata from Aegean Sea was studies for its antimicrobial activity against Candida albicans the ethanolic extract showed considerable activity while the extract of diatom Nitzschia communis showed effective results against Gram-positive bacterium, S. aureus. Laurencia papillosa a red algae and three Cystoseira species extracts showed selective antiproliferative activity against cancer cell lines whereas Dilophus fasciola a brown alga showed the highest anti-inflammatory activity as measured in primary microglial and astrocyte cell cultures and also by reduction of pro-inflammatory cytokines (Montalvao et al., 2016).

Bacillus subtilis sub spp. spizizenii and $B$. thuringiensis isolated from hydrothermal vent region of Azorean Island Faial, North Atlantic Ocean exhibited antagonistic activity in their cell free extracts against Vibrio cholera serogroup 01 and Staphylococcus aureus, respectively. Both bacterial strains showed sensitivity to protease test indicating the proteinaceous nature of the antibacterial substances. Zebra fish animal model was used instead of antibiotic test to evaluate the toxicity studies including heat resistance, proteinaceous nature and bacteriostatic mode of action. The Staphylococcus aureus-zebra fish embryo infection studies indicated that Bacillus showed no toxic effects (Ravindran et al., 2016).

Kahalalide F (KF) along with two unprecedented related peptides were isolated from ethanolic-methanolic extracts of Elysiaornata mucus demonstrating antifungal activity. The kahalalides $\mathrm{Z}$ exhibited significant antimicrobial properties against various fungal pathogens which infected many economically important plants, food and fish.The Kahalalides were also found to inhibit the in-vitro growth of a series of cancer cell lines comparable to that of with KF (Ciavatta et al., 2016).

Ethyl acetate and chloroform extracts of Penicillium chrysogenum strain isolated from Tedaniaanhelans (marine sponge) from Indian Ocean 
exhibited antibacterial activity with later showing more activity. The chloroform extract showed activity against Mycobacterium tuberculosis H37Ra, Mycobacterium avium, Mycobacterium fortuitum, Mycobacterium smegmatis, Mycobacterium vaccae, Staphylococcus aureus, Aeromonas hydrophila, Pseudomonas aeruginosa and Vibrio cholerae. The extract did not show cytotoxic ctivity in vero cell lines. Antibacterial activity might be due to diketopiperazines, Cyclo-(L-Pro-L-Phe) and Cyclo(L-Leu-L-Pro) produced by the associated fungi- $P$. chrysogenum (Visamsetti et al., 2016).

Stylissamide G a natural heptacyclopeptide, previously isolated from the Bahamian marine sponge Stylissacaribica from the Caribbean Sea, was synthesized by coupling of the tetrapeptide 1phenylalanyl-1-prolyl-1-phenylalanyl-1-proline methyl ester with the tripeptide Boc-1-leucyl-1-isoleucyl-1proline, followed by cyclization of the linear heptapeptide fragment (Fig. 4). It displayed good antihelminthic potential against Megascoplex konkanensis, Pontoscotex core thruses and Eudrilus eugeniea, and potent antifungal activity against pathogenic Candida albicans and dermatophytes Trichophyton mentagrophytes and Microsporum audouinii (Dahiya et al., 2016).

Fungistatic activity against pathogenic Candida albicans was exhibited by peptide Cm-p5 (SRSELIVHQRLF derived from the marine mollusc Cenchritis muricatus. The peptide also exhibited low toxic effects against a cultured mammalian cell line. Cm-p5 possessed alpha-helical structure a characterized by circular dichroism and nuclear magnetic resonance revealed an alpha-helical structure and a tendency to random coil folding in aqueous solutions. $\mathrm{Cm}$-p5 also has a high affinity for the phospholipids of fungal membranes (phosphatidylserine and phosphatidylethanolamine), and lesser affinity to mammalian membrane phospholipid. It also showed low interaction with ergosterol and no interaction with chitin (Lopez et al., 2015).

Caulerpa racemosa, a marine alga was used to synthesize Silver nanoparticles which exhibited good antibacterial activity against human pathogens such as Staphylococcus aureus and Proteus mirabilis (Kathiraven et al., 2015).
Pond sediments of Ribandar saltern, Goa were studied in three media viz. Starch casein, R2A and Inorganic salt starch agar at various salinities. Halotolerant and halophilic Actinomycetales producing anti-bacterial metabolites were identified. Most of them were halotolerant Streptomyces Spp. others being rare actinomycetes viz. Nocardiopsis, Micromonospora and Kocuria spp. More than 50\% of the isolates showed anti-bacterial activity against one or more of the fifteen human pathogens tested. Eight strains from 4 genera were studied in detail and showed consistent anti-bacterial activity. Multiple inhibitions against test organisms were shown by four Streptomyces strains while four rare actinomycetes were specific in their inhibitory activity. Halophilic Kocuria spp., Nocardiopsis spp., and halotolerant Micromonospora spp. produced anti-bacterial compound(s) against Staphylococcus aureus, Staphylococcus citreus, and Vibrio cholerae, respectively. This indicated that halophilic and halotolerant actinomycetes from marine salterns are a potential source of anti-bacterial compounds (Ballav et al., 2015).

Dual behaviour of the marine antimicrobial peptides (AMP), tachyplesin was studied. This cyclic peptide is known to possess antimicrobial properties. It was further investigated for its cell-penetrating property and cargo delivery ability. It showed higher stability in vitro due to its marine nature and cyclic structure. Its role as cell-penetrating peptide is well known. Since it delivers cargo molecules in both living systems, it is an efficient nonviral macromolecule nanocarrier (Jain et al., 2015).

A marine bacterium with mosquitocidal effect was isolated from the gut region of the marine red snapper fish (Lutjanus sanguineous). The isolated bacterium belonged to the strain Bacillus cereus VCRC-B540. Biochemical studies showed that the strain could be useful in mosquito control. It exhibited toxicity against Culex quinquefasciatus, Anopheles stephensi and Aedes aegyptii, without negative effects for the non-targeted organisms Chironomus riparius, Daphnia cephalata and Notonecta glauca. A polypeptide (M.wt: $90 \mathrm{kDa}$ ) identified as a surface layer protein was instrumental for the toxicity observed (Mani et al., 2015). 
The larvicidal potential of the Taiwanese seaweed Gracilaria firma and extracts combined with the copepod Megacyclops formosanus were studied for controlling dengue vector Aedes aegyptii. Methanolic extract of G. firma showed significant larvicidal activity against $A$. aegypti larvae. This could provide an eco-friendly approach to eradicating larvae of the dengue vector A. aegyptii (Kalimuthu et al., 2014).

Secondary metabolites isolated from eighty four different fungal endophytes from sea grasses (5), marine algae (36) and leaves or barks of forest trees (43) grown in vitro were harvested by immobilizing them on XAD beads. They exhibited antiplasmodial activity against blood stage Plasmodium falciparum in human red blood cell culture using SYBR Green I assay.The studies indicated that fungal endophytes can be an untapped resource for secondary metabolites showing various bioactivities including anti malarials (Kaushik et al., 2014).

A bacterium isolated from marine soil of strain, Enterobacter cloacae VCRC-B519 showed toxicity for Culex quinquefasciatus, Anopheles stephensi and Aedes aegyptii, in increasing order without negative effects for non-targeted organisms Chironomus riparius, Daphnia cephalata and Notonecta glauca. E. cloacae analyses indicated the toxicity exhibited was due to three polypeptides (M.wt: 25, 30 and $50 \mathrm{kDa}$ ). The polypeptides were found to be enzymatic in nature and their peptide sequences were identified to be polysugar degrading enzymes $(25 \mathrm{kDa})$, cell wall associated hydrolases $(30 \mathrm{kDa})$ and amino peptidase $(50 \mathrm{kDa})$ (Poopathi et al., 2014).

Marine Streptomyces spp. VITJS4 crude extracts were studied for their larvicidal and repellent activities. The ethyl acetate crude showed 100\% mortality for all the 3 species after $24 \mathrm{~h}$ exposure against the early fourth instar larvae of malarial vector Anopheles stephensi, dengue vector-Aedes aegyptii and filariasis vector -Culex quinquefasciatus. The ethyl acetate extract also showed complete protection against these mosquito bites (Naine and Devi, 2014).

Mosquitocidal bacterium isolated from marine soil from east coastal areas of Pondicherry (India) belonged to Bacillus cereus VCRC-B520 .Toxicity assay indicated that the bacterium isolate was more effective against filariasis vector, Culex quinquefasciatus, than the other two species (Anopheles stephensi and Aedesa egyptii). The protein identified was an endotoxin-specific insecticidal, namely "Cry4Aa" $(85 \mathrm{kDa})$ for mosquitocidal action, thus providing an environmental friendly alternative to synthetic pesticides (Poopathi et al., 2014)

Six known norcembranoids(1-6) and one new compound, named kavaranolide extracted from the Indian soft coral, Sinularia kavarattiensis showed promising activity against the Chikungunya virus (CHIKV) replicon. Compounds 1-3 and 5-7 (Fig. 5) isolated from crude extract and exhibited repliconinhibiting potential in the CHIKV model by using a luminescence-based detection technique and live cell imaging. Compounds 1 and 2 along with CHIKV replicon inhibition also showed cytotoxic properties. Compound 2 showed anti-inflammatory activity due to release of pro- and anti-inflammatory cytokines (Lillsunde et al., 2014).

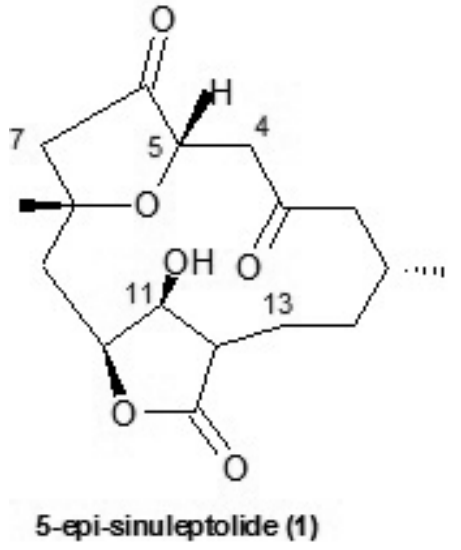

Fig. 5A:

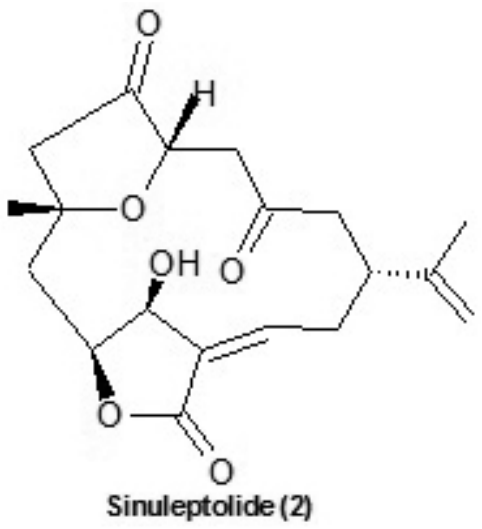

Fig. 5B: 


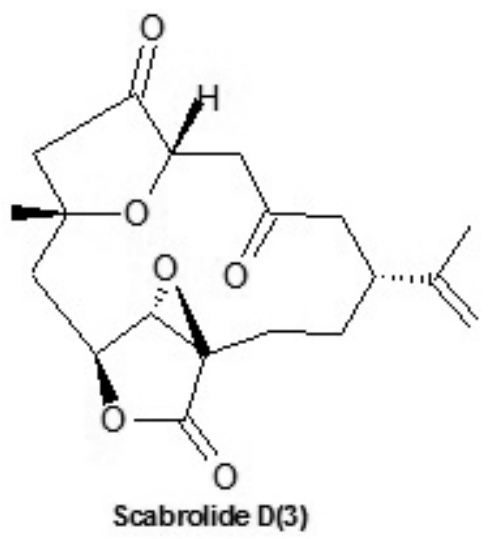

Fig. 5C:

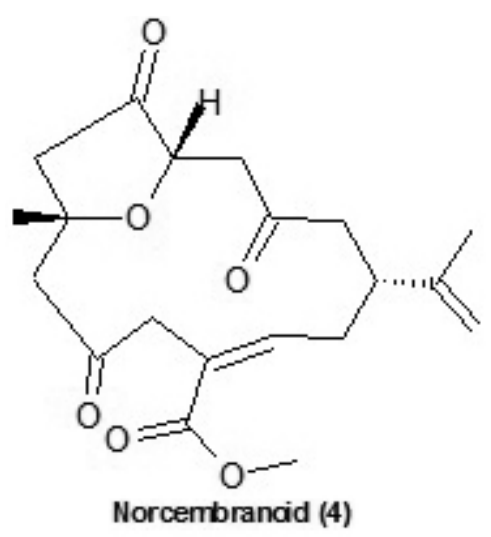

Fig. 5D:

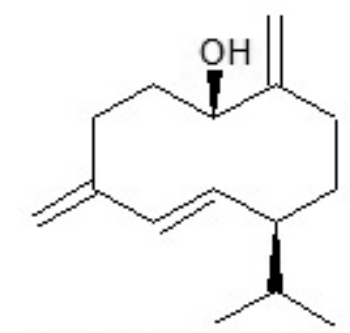

ent-germacra-4(15),5E,10(14)-triene-1 $\beta$-ol (5)

Fig. 5E:

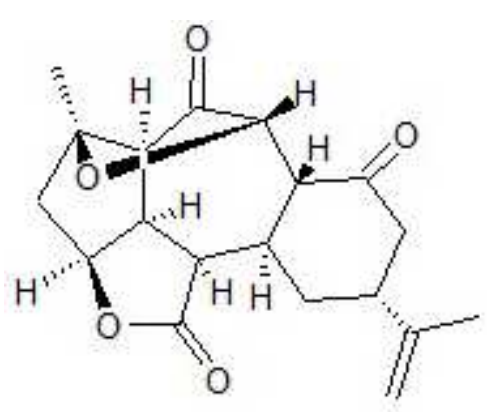

Ineleganolide (6)

Fig. 5E:
Isatin and its synthetic analogues were evaluated for their antibacterial. Few synthetically modified isatin exhibited potent inhibitory activity against Planococcus donghaensis, Erythrobacter litoralis, Aliivibrio salmonicida and Vibrio furnisii. The study showed that the modified analogues showed better anti-inflammatory activity than their parent marine compound isatin. The modified analogue $1 \mathrm{H}$-indole-2, 3-dione can be used as antifouling anti-inflammatory agent (Fig. 6) (Majik et al., 2014).

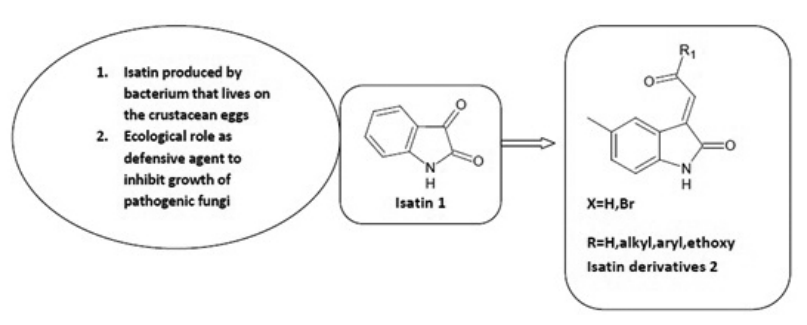

Fig. 6:

Twenty-nine actinobacterial strains isolated from marine sponge Spongia officinalis and showed antagonistic activity against various bacterial and fungal pathogens. The strain that produced the active antibiotic MAPS15 was identified as Streptomyces spp. active fraction was purified and characterized and assumed to be a pyrrolidone derivative which showed bioactivity against different pathogens suggesting that this strain can be utilized to produce antibiotics. (Sathiyanarayanan et al., 2014).

Bacterial biosymbionts associated with marine sponges from Gulf of Mannar, South Coast India exhibited antimicrobial potential of the flurophoric and chromophoric metabolites extracted. The metabolites extracted showed high therapeutic potential against many bacterial pathogens including multidrug-resistant strains. The secondary metabolites were characterized and were found to be quinones, alkaloids, flavanoids and flavonyl glycosides. Ethyl acetate extracts of chromophore and floureophore substances showed significant inhibitory properties against Methicillin resistant Staphylococcus aureus (MRSA) and Salmonella typhi respectively. The chomophore-producing strain were closely related to Pseudomonas spp. RHLB12, isolated from Callyspongia spp. and floureophore-producing bacteria was related to Bacillus licheniformis T6-1 which was isolated from Haliclona spp. (Skariyachan et al., 2014). 
Methanol extract of thirty-eight seaweeds samples were screened against Laurencia papillosa (Ceramiales, Rhodomelaceae, Rhodophyta) exhibited highest antimicrobial activity among the thirty eight seaweed samples screened against Grampositive (Staphylococcus aureus ATCC 25923 and Bacillus subtilis ATCC 6051) and gram negative (Escherichia coli ATCC 8739 and Pseudomonas aerugenosa ATCC 9027) bacteria. It also exhibited antibacterial activity against four clinical Gramnegative isolates (E. coli, $P$. aerugenosa, Klebsiella pneumoniae and Shigella flexineri). The active fraction was identified as a cholesterol derivative, 24propylidene cholest-5-en-3 beta-ol (Fig. 7) (Kavita et al., 2014).

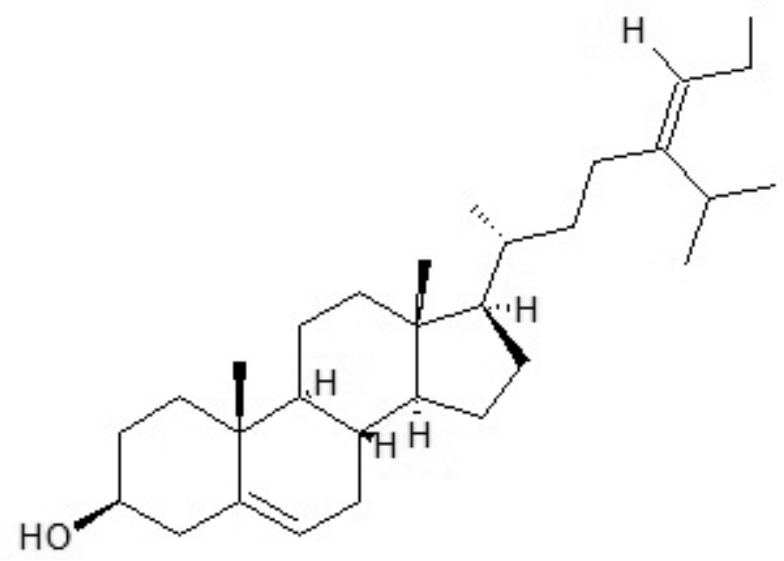

Fig. 7:

A group of 168 marine bacteria isolated from different marine organisms from Pulicat lake, coromandal coast in south India, were tested against five test strains, viz., Escherichia coli, Klebsiella pneumoniae, Pseudomonas aeruginosa, Staphylococcus aureus and Candida albicans. Of these the two bacterial strains, S. aureus and $K$. pneumoniae showed broad spectrum antibacterial activities (Chellaram and Praveen, 2014).

In-vivo screening of Alcaligenes faecalis from Caenorhabditis elegans showed that it inhibits the virulence of Vibrio alginolyticus by interrupting the QS pathway. The study showed that C. elegans based in-vivo screening method can be used to identify bioactives (Durai et al., 2013).

Organic extracts of seaweeds (Ulva fasciata and Hypnea musciformis), sponges (Dendrilla nigra, Axinella donnai and Clathria gorgonoides) and a holothurian (Holothuria scabra) were used for the detection of microalgal lethality potential. Antifouling activity of $H$. Scabra may be due to its toxic secondary metabolites. Although all extracts inhibited the growth of microalgae at various concentrations except $H$. musciformis and $A$. donnani, which showed reverse effect by inducing the growth of microalgae to certain extent. Suggesting that 'microalgal lethality bioassay' can be used for the detection of biotoxic and antifouling agents from marine organisms (Manilal et al., 2013).

Bacillus licheniformis strain D1 isolated from the surface of green mussel, Perna viridis showed antimicrobial activity against pathogenic Candida albicans $\mathrm{BH}$, Pseudomonas aeruginosa $\mathrm{PAO} 1$ Bacillus pumilus TiO1 cultures. On analysis antimicrobial agent was found to be a $14 \mathrm{kDa}$ protein designated as BL-DZ1. The protein inhibited microbial growth, decreased biofilm formation and dispersed pre-formed biofilms of the representative cultures in polystyrene microtiter plates and on glass surfaces (Dusane et al., 2013).

Bacillus licheniformis, collected off the coast of Cochin, India, inhibited the growth of Gram-positive test organisms. Bacteriocin BL8 was found to be $\mathrm{pH}-$ tolerant and thermostable and active against the tested Gram-positive bacteria, was isolated from Bacillus licheniformis. This bacteriocin can be an effective therapeutic agent and can be used as biopreservative in food processing industry (Smitha and Bhat, 2013).

The acaricidal and insecticidal property of ethyl acetate extract and its compounds isolated from marine actinobacteria, Streptomyces VITSTK7 sp were evaluated against the larvae of cattle ticks, Haemaphysalis bispinosa and Rhipicephalus (Boophilus) microplus (Acari: Ixodidae); fourthinstar larvae of malaria vector, Anopheles subpictus; and filarial vector, Culex quinquefasciatus. The identified compounds were cyclopentanepropanoic acid, 3,5-bis(acetyloxy)-2-[3-(methoxyimino)octyl], methyl ester (structure1, Fig. 8); 5-azidomethyl-3-(2ethoxy carbonyl-ethyl)-4-ethoxycarbonylmethyl-1Hpyrrole-2-carboxylic acid, ethyl ester (structure 2, Fig. 8); and akuammilan-16-carboxylic acid, 17(acetyloxy)-10-methoxy, methyl ester (16R) (structure 3 , Fig. 8). The maximum efficacy was observed in compounds 1,2 , and 3, and the ethyl acetate extract 


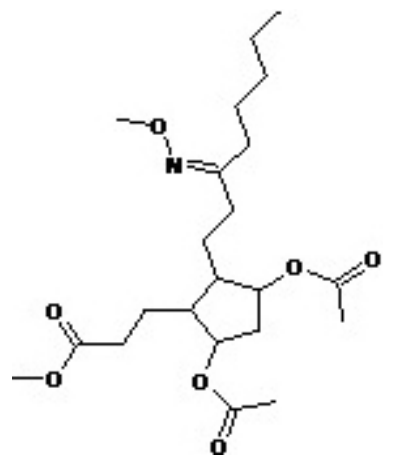

Fig. 8A:

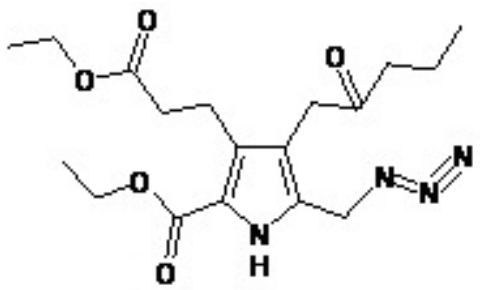

Fig. 8B:

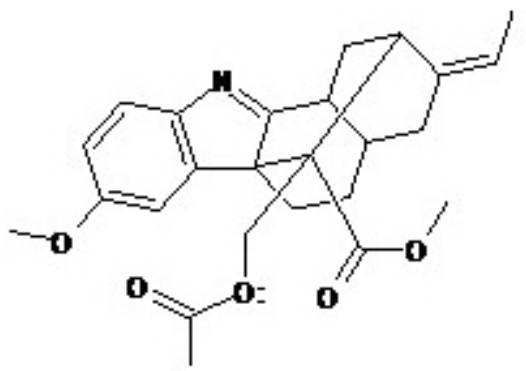

Fig. 8C:

of Streptomyces VITSTK7 sp. against the larvae of $H$. bispinosa, R. microplus, A. subpictus and $C$. Quinque fasciatus (Fig. 8) (Thenmozhi et al., 2013).

An indole and a diketopiperazine moiety were isolated from the culture medium of Penicillium chrysogenum, (MTCC 5108), an endophytic fungus on the mangrove plant Porteresia coarctata (Roxb.). The cell free culture medium of $P$. chrysogenum showed effective activity against Vibrio cholerae, (MCM B-322), a pathogen causing cholera in humans. On chemical analysis compound of formula $\mathrm{C}_{19} \mathrm{H}_{21} \mathrm{O}_{2} \mathrm{~N}_{3}$ was isolated. Its antibacterial activity was comparable with standard antibiotic, streptomycin. This was found to be $(3,1$ '-didehydro3[2aEuro(3)(3'aEuro(3),3' aEuro(3)-dimethyl-prop-2enyl)-3aEuro(3)-indolylmethylene]-6-methyl piperazine-2,5-dione) (Fig. 9) (Devi et al., 2012).

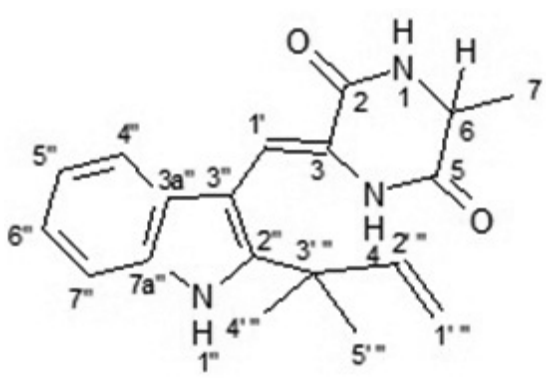

Fig. 9:

Bio-silver nanoparticles were synthesised from Marine algae Padina pavonica (Linn.) thallus broth. The thallus extract as well as silver-based nanoparticles of marine alga, P. Pavonica (Linn.) were tested against two important pathogens of cotton. Fusarium wilts (Fusarium oxysporumf. Spp. vasinfectum) and bacterial leaf blight (Xanthomonas campestris pv. malvacearum). The $P$. pavonica based silver nanoparticles inhibited the growth of the test pathogens and can be used for the management of cotton phytopathogens (Sahayaraj et al., 2012).

A 100 heterotrophic, halophilic bacterial bionts isolated from 9 sponges, 5 corals and one bivalve were evaluated for their antibacterial activity. Culture broths of 46 of these bionts were active against human pathogenic bacteria namely Staphylococcus citreus, Proteus vulgaris, Serratio marcesans, Salmonella typhi, Aerobacter aerogenes and Escherichia coli. Larger number of bionts was isolated from corals followed by sponges and bivalve. Making them rich source of bioactive secondary metabolites against human bacterial pathogens (Velho and Furtado, 2012).

Ascidian Lissoclinum fragile, found in the coastal waters of Tuticorin Southeast coast of India were investigated for their bioactive potential. In antibacterial assay bacterial pathogen, $S$. typhi exhibit high zone of inhibition against dichloromethane extract. In antifungal assay, fungal pathogen Penicillium species showed high zone of inhibition against nbutanol extract. In haemolytic assay, n-butanol extract showed high heamolytic activity in chicken erythrocytes, goat erythrocytes and cow erythrocytes. In cytotoxic activity, n-butanol extract exhibited high $\mathrm{LC}_{50}$ value against brine shrimps indicating that the ascidian $L$. fragile has remarkable antimicrobial, haemolytic, and cytotoxic activities (Kumaran et al., 2012). 
Four species of seaweeds collected from the Kollam coast (Indian Ocean) were used to isolate 27 epiphytic bacteria and investigated for antagonistic activity by cross streak method. Of the 27 bacterial isolates, 4 strains inhibited the growth of at least one shrimp Vibrio pathogen tested. The SWI-24 strain exhibited highest spectrum of activity against all the tested shrimp pathogens. The active isolate of SWI24 was found to be Pseudoalteromonas spp. and further reflect the potential use of seaweed-associated bacteria in managing the shrimp/fish disease (Sugathan et al., 2012).

Twenty five marine soil samples were collected from the region of Palk Strait of Bay of Bengal, Tamil $\mathrm{Nadu}$, and were subjected to the isolation of actinomycetes. Sixty-eight morphologically distinct isolates were obtained and $37 \%$ i.e. twenty five of them had antimicrobial activity. The phylogenetic evaluation categorized the organism as Streptomyces afghaniensis VPTS3-1 (Vijayakumar et al., 2017).

The leaf extracts of Rhizophora mucronata L., were screened for antibacterial activity against multi-drug resistant Vibrio harveyi and Vibrio campbellii isolated from Lobster's larvae hatchery water. V. harveyi was found highly resistant to ampicillin, oxacillin, cephalothin, vancomycin, erythromycin, and clidamycin, but sensitive towards chloramphenicol and gentamycin. Whereas, Vibrio campbellii was found highly resistant to ampicillin, oxacillin, cephalothin, vancomycin, and erythromycin, Vibrio campbellii was highly sensitive to chloramphenicol and moderately sensitive to clindamycin, and gentamycin. Chloroform leaf extract of Rhizophora mucronata L. Showed highest activity against both Vibrio spp., while, hexane, ethyl acetate, and methanol extract revealed moderate activity against both Vibrio spp. (Baskaran and Mohan, 2012).

Thirty-three bacterial isolates were isolated from Haliclona grant, and the extracellular ethyl acetate extracts were screened for antiplasmodial activity against Plasmodium falciparum. The antiplasmodial activity of bacterium RJAUTHB 14 is highly comparable with the positive control chloroquine. The antiplasmodial activity may be due to the presence of reducing sugars and alkaloids in the ethyl acetate extracts of bacterium RJAUTHB 14 (Inbaneson and Ravikumar, 2012).
The antioxidant and antimicrobial activities of Chaetomorpha linum from the Mandapam coastal region of the Gulf of Mannar, on the southeast coast of India, were examined based on the free radicalscavenging activity of the 1,1-diphenyl-2picrylhydrazyl radical (DPPH), ferrous reducing antioxidant property (FRAP), and total phenolic content in the methanolic extract. Indicating that $C$. linum has potential as a natural antioxidant and a natural source of antimicrobials against many microbes (Senthilkumar and Sudha, 2012).

Chloroform extract of Rhizophora mucronata, collected from Pitchavaram, Muthupett and Manakudy regions of Tamilnadu, were chromatographed for identification of triterpenoids such as betulin and lupeol proving their antimalarial and antiviral activities (Hridya et al., 2012).

Fasciospongia cavernosa doc var. brown (dark brown) and Fasciospongia cavernosa doc var.yellow (yellow) were collected from the Vishakhapatnam coast of Bay of Bengal and investigated for their antimicrobial activity. 178 microorganisms isolated from different parts of the two sponges mostly from the middle part of the sponge and showed antimicrobial activities against Gram-positive (Staphylococcus aureus, Bacillus subtilis, Bacillus cereus) Gramnegative bacteria (Pseudomonas aeruginosa, Escherichia coli, Proteus vulgaris), fungi (Candida albicans, Aspergillus niger) and 10 other pathogenic organisms (Kumar et al., 2012).

Themethanolic and crude extract of brown alga, Lobophora variegata showed toxicity in all organisms including pathogenic bacteria, mosquito pupae, nematodes and plant seeds in the given order i.e. highest for pathogenic bacteria and least for plant seeds. The fatty acids present in the fraction of $L$. variegata extract may be responsible for the said activity (Manilal et al., 2012).

\section{Anti Cancer/Cytotoxic Activity}

A 131 isolates belonging to the phylum: Gammaproteobacteria (63\%), Bacillales (34\%) and Micrococcaceae (3\%) were isolated from surficial sediments of south east Arabian Sea and evaluated. Among these, about $40 \%$ of the isolates showed the presence of secondary metabolite biosynthetic genes such as PKS or NRPS or both. Nearly $50 \%$ were 
cytotoxic to human breast cancer MCF-7 cells and were bactericidal to human pathogens, Escherichia coli and Pseudomonas spp., while 20-30\% of them were bactericidal to Vibrio spp. and Staphylococcus spp. In all, 8 isolates, belonging to Pseudomonas spp., Bacillus spp. and/or Lysinibacillus spp. displayed high level of bactericidal and cytotoxic properties (Anas et al., 2016).

Marine stingray Dasyatis sephen produced venom which was found to enhance lipid peroxidative markers such as thiobarbituric acid reactive substance, conjugated diene, and lipid hydroperoxide in HeLa cell lines. Stingray venom apart from increasing ROS levels also altered the mitochondrial membrane potential in HeLa cells. Apoptotic morphological alterations in $D$. sephen venom-treated groups were also increased (Rajesh Kumaret al., 2015).

Anticancer activity of ethanolic extract of Sargassum wightii Greville a marine brown alga belonging to the Sargassaceae family was investigated in mice using DAL cell lines to induce cancer. Cancer cell counts in mice were significantly increased on intraperitoneal inoculation of DAL cells. This increase in cancer cell count upon administration of ethanolic extract of $S$. wightii indicates that the brown alga has a significant inhibitory effect on the tumor cell proliferation. Administration of ethanolic extract also showed a significant decrease in tumor weight, restored the hematological parameters in DAL-treated mice and hence increased the lifespan of DAL-treated mice (Anjana et al., 2014).

Antitumor potential of ethanolic extract of Gracilaria edulis J. Ag (Brown algae) was evaluated against the Ehrlich ascites tumour in-vivo and invitro. In-vitro cytotoxic studies indicated that ethanol extract of Gracilaria edulis showed cytotoxicity to Ehrlich ascites tumour cells due to its ability to produce reactive oxygen species and therefore decreasing intracellular glutathione responsible for the apoptotic activity of the extract (Patra and Muthuraman, 2013).

The antiangiogenic and antiproliferative activity of Chlorella pyrenoidosa was evaluated in experimental models of angiogenesis and by cell proliferation assay (MTT). The secondary metabolites of $C$. pyrenoidosa extract indicated significant antiangiogenic activity against vascular endothelial growth factor induced neovascularization and antiproliferation activity of the assay (Kyadari et al., 2013).

The anti-metastatic potential of the methanolic extract of Rhizophora apiculata (R. apiculata) was evaluated using the B16F-10 melanoma induced lung metastasis model in mice. Administration of the methanolic extract inhibited the pulmonary tumor nodule formation as well as increased the life span (survival rate) of the metastatic tumour bearing mice. It also reduced biochemical parameters such as lung collagen hydroxyproline, hexosamine, uronic acid content, serum nitric oxide (NO), gammaglutamyltranspeptidase (GGT) and sialic acid levels when compared to metastasis controls (Prabhu and Guruvayoorappan, 2013).

Four lead compounds (RL381, RL366, RL376 and RG012) were analysed for their ability to bind at taxol binding site. They showed better interactions with the H1-S2 loop and M-loop which are actively involved in lateral interactions of tubulins and also with the helix $\mathrm{H} 7$ which is the connecting link between $\mathrm{N}$ terminal and intermediate domain. The residues obtained by these lead compounds on polar interaction were D224, H227, R276, R282 and R359 which closely mimicked the interaction of taxol with betatubulin (Fig. 10) (Kumar et al., 2013).

The anti-inflammatory and anti-tumour activity ofmethanolic extract of Rhizophora apiculata was

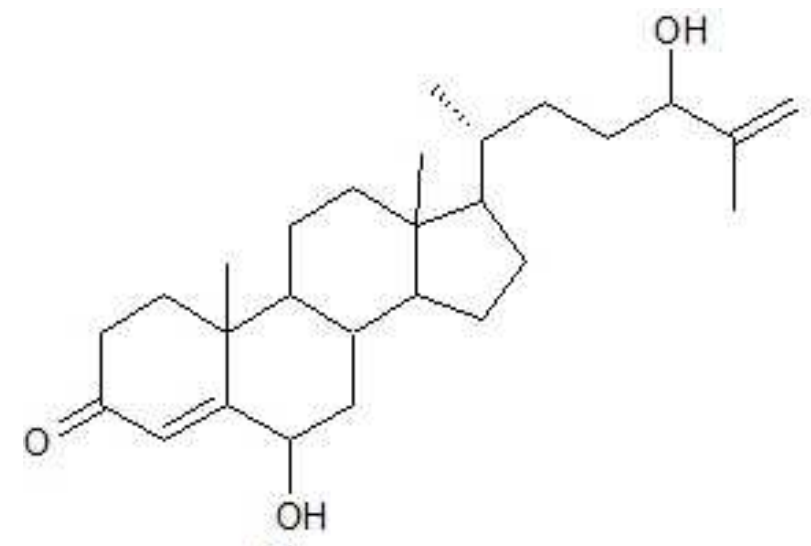

(a)

Fig. 10A: 


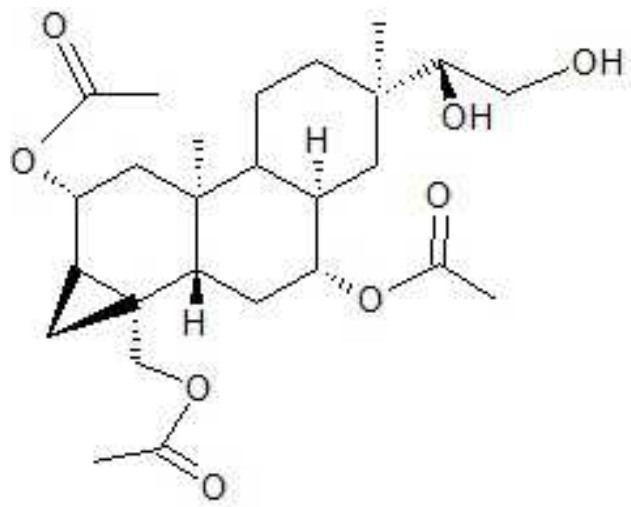

(b)

Fig. 10B:

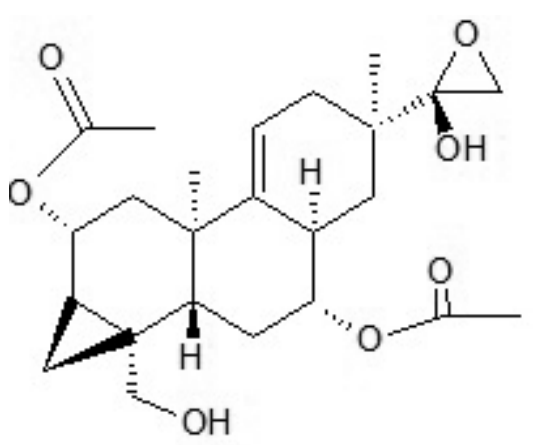

(c)

Fig. 10C:

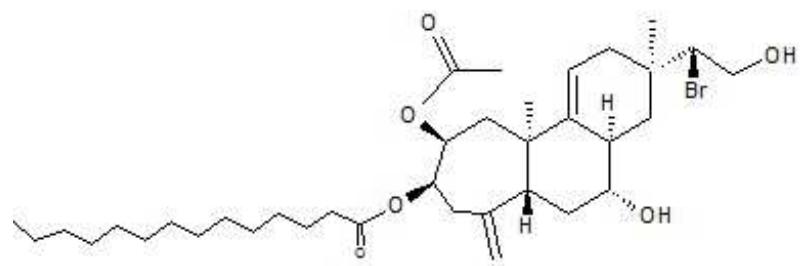

(d)

Fig. 10D:

evaluated against B16F10 melanoma cells in mice. $R$. apiculata extract was shown to inhibit the solid tumour development, significantly reduced tumor cell glutathione (GSH) levels, serum gammaglutamyltranspeptidase (GGT) and nitric oxide (NO) levels in the tumor-induced mice. The extract also reduces total white blood cell count and hemoglobin levels in tumour bearing mice. It also reduced acute inflammation (assessed as paw edema) induced by carrageenan and inflammation edema induced by formalin. Themethanolic extract was found to possess active constituents like 4-pyrrolidinyl, pyrazole, and ketone derivatives (Prabhu and Guruvayoorappan, 2012).

\section{Immunostimulant/Immunomodulatory}

Common carp Cyprinus carpio which fed on marine alga, Padinagymno spora rich in polysaccharides was found to have active immune system. Diet rich in polysaccharide protected the fish from its common pathogens like Aeromonas hydrophila and Edwardsiella tarda with relative percent survival (RPS) values of 80 and 60 respectively. The immune parameters like serum lysozyme, myeloperoxidase activities and antibody response were also improved in the fish which took algal diet. Immunostimulation by $P$. gymnospora might be due to the increased secretion of cytokine interleukin-1 beta (IL-1 beta) and antimicrobial peptide lysozyme-C (Rajendran et al., 2016).

Seven Monoindole derivatives isolated from the $\mathrm{MeOH}$ extract of marine sponge Spongosorite shalichondriodes from western coast of India (Fig. 11). The investigation of immunomodulatory activities of methanolic extract were studied for acute toxicity. Parameters studied for Immunomodulatory potential were Haemagglutinating antibody (HA), delayed-type hypersensitivity (DTH) response and cyclophosphamide-induced myelosuppression. Marine sponge Spongosorite shalichondrioides was found<smiles>[R]c1ccc2c(C(=O)C(=O)OC)c[nH]c2c1</smiles><smiles>[R]c1ccc2c(C(=O)C(=C)N)c[nH]c2c1</smiles>

$4 \mathrm{R}=\mathrm{H}$

$5 \mathrm{R}=\mathrm{Br}$<smiles>[R]c1ccc2c(C(=O)OC)c[nH]c2c1</smiles>

$6 \mathrm{R}=\mathrm{OH}$

$7 \mathrm{R}=\mathrm{H}$

Fig. 11: 
to have immunosuppressant activity and may possess compounds which can be used for organ rejection treatment (Kumar MS et al., 2012).

\section{Wound Dressing}

A collagen films (CF) was prepared using the bones of Bluefin trevally (BT) which showed potential as a wound dressing material. CF showed biocompatibility to human keratinocyte cell line $(\mathrm{HaCaT})$ and better mechanical properties in in-vitro studies. The CF film treated mice also showed faster wound healing properties demonstrating that fish waste can be used for the preparation of a value-added product like wound dressing material (Rethinam et al., 2016).

Fish scales a biological waste product in marine food industry was used to prepare collagen sponge. Collagen sponge incorporated separately with drug mupirocin and Macrotylomau niflorum plant extract. The incorporated collagen sponge enhanced wound healing and was involved in the increase of growth factors such as vascular endothelial growth factor, fibroblast growth factor, epidermal growth factor and transforming growth factor beta. Increased levels of hydroxyproline, hexosamine and uronic acid were observed in the Macrotyloma uniflorum plant extract treated group compared with the other groups. The Macrotyloma uniflorum plant extract collagen sponge reduced inflammation and accelerated matrix metalloproteinases and scar formation, thereby contributing to faster wound healing (Muthukumar $e t$ al., 2014).

Wound healing activity of Type I collagen extracted from the bone of two marine fishes; Magalaspiscordyla and Otolithesruber were studied. The cross-linked structure of collagen with glutaraldehyde with three dimensional pores improved the wound healing property of the bandage (Kumar et al., 2012).

\section{Antidiabetic}

Evaluation of four green algae Chaetomorpha aerea, Enteromorpha intestinalis, Chlorodesmis Spp., and Cladophora rupestris for in-vitro alpha-amylase, alpha-glucosidase inhibitory, and antioxidant activity showed that chloroform extract of $C$. aerea and methanol extract of Chlorodesmis showed effective inhibition against alpha-amylase. Methanol extract of C. rupestris indicated free radical scavenging activity. Phenol, 2, 4-bis (1, 1-dimethylethyl) and z, z-6,28heptatriactontadien-2-one were major constituents in the methanol extract of $C$. rupestris and chloroform extract of C. Aerea (Fig. 12) (Unnikrishnan et al., 2015).

A significant number of marine bacteria under wide range of bacterial phyla such as Firmicutes (23), Actinobacteria (9), Proteobacteria (7) and Bacteroidetes (1), were found to produce betaglucosidase inhibitors for use as anti-diabetics, anti-

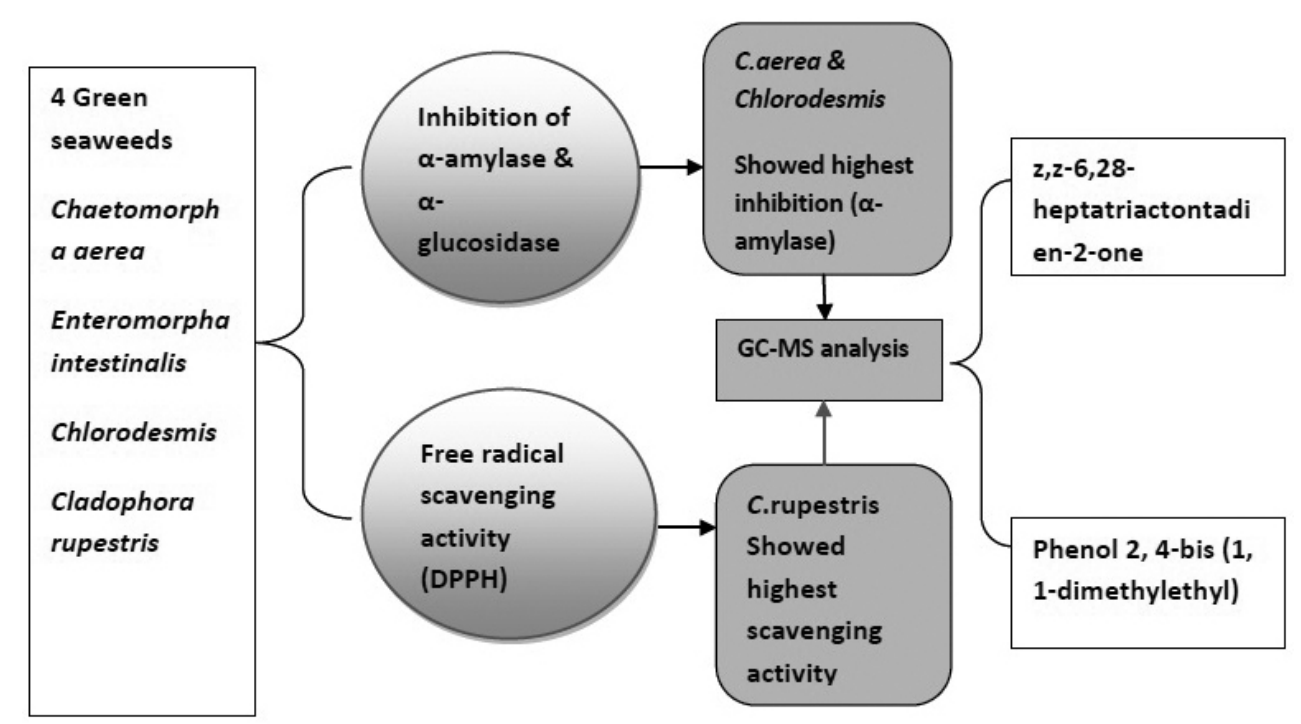

Fig. 12: 
obesity and anti-tumour compounds (Pandey et al., 2013).

\section{Miscellaneous}

The screening of 887 marine bacteria for acetylcholinesterase inhibitors showed that 140 of them inhibit the electric eel enzyme, acetylcholinesterase in a microplate based assay. Larger amount of acetylcholinesterase inhibitors were bacterial associates of soft corals followed by sediment isolates while most of the potent inhibitors belonged to the bacterial associates of marine sponges. The strain M18SP4P showed maximum inhibition (54\%) and was isolated from the marine sponge Fasciospongia cavernosa. The strain was identified as Bacillus subtilis (Pandey et al., 2014).

The herbicidal activity of the crude extracts and partially purified fractions of Trochus tentorium was assayed using the duckweed, Lemna minor L. by benchtop bioassay. The crude acetone extract of $T$ tentorium decayed the fronds of Lemna plants on the 4th day, while ethyl acetate, dichloromethane and methanol extracts showed decay of the plants on the 5 th day of the experiment. The study indicated that column purified acetone fractions of the gastropod was able to decay L. minor to a better degree in

\section{References}

Ahamed A A P, Rasheed M U, Noorani K P M, Reehana N, Santhosh Kumar S, Imran Y M M, Alharbi N S, Arunachalam C, Alharbi S A, Akbarsha M A and Thajuddin N (2017) In vitro antibacterial activity of MGDGpalmitoyl from Oscillatoria acuminata NTAPC05 against extended-spectrum beta-lactamase producers Journal of Antibiotics 70 754-762

Alam M A, Sarkar S K and Gomes A (2012) A high molecular weight protein extract of Mastobranchusindicus (Mi-64) having antiarthritic activity in experimental animals Inflammation 35 1223-1231

Anas A, Nilayangod C, Jasmin C, Vinoth Kumar S, Parameswaran P S and Nair S (2016) Diversity and bioactive potentials of culturable heterotrophic bacteria from the surficial sediments of the Arabian Sea 3 Biotech Dec 6238

Anjana A, Ahamed K F H N, Ravichandiran V, Sumithra M and Anhu J (2014) Anticancer activity of Sargassum wightii comparison with the crude extracts. (Chellaram et al., 2012).

The anti-genotoxic potential of crude aqueous extracts of Kappaphycus alvarezii (Rhodophyceae), collected from the Southeast coast of India was evaluated. Aqueous extract of $K$. Alverazii was found to interfere with the clastogenicity induced by mercury chloride $\left(\mathrm{HgCl}_{2}\right)$ in marine fish, Therapon jarbua by measuring cytogenetic endpoints like cell viability and comet assay. The result indicated the use of $K$ alvarezii extract as fish supplement to reduce mercury poisoning in them as well avoiding human consumption of infected fish (Nagarani et al., 2012).

Gold nanoparticles (AuNPs) were produced using marine bacteria Marinobacter pelagius. Stable, monodisperse AuNP with $10 \mathrm{~nm}$ dimension approximately were obtained by exposure of $\mathrm{HAuCl} 4$ solution to whole cells of a bacterial strain (Sharma et al., 2012).

\section{Acknowledgement}

The authors duly acknowledge the significant contributions from Sivakami A. Dhulap, Pravin Shinde from CSIR-URDIP, Pune and Zeba Siddiqui (DSTIndia, TIFAC KIRAN-IPR Intern) at CSIR-CDRI.

Greville on Dalton's ascitic lymphoma Chinese Journal of Natural Medicines 12 114-120

Badrinathan S, Shiju T M, Christa A S S, Arya R and Pragasam V (2012) Purification and structural characterization of sulfated polysaccharide from Sargassummyrio cystum and its efficacy in scavenging free radicals Indian Journal of Pharmaceutical Sciences 74 549-555

Ballav S, Kerkar S, Thomas S and Augustine N (2015) Halophilic and halotolerant actinomycetes from a marine saltern of Goa, India producing anti-bacterial metabolites Journal of Bioscience and Bioengineering 119 323-330

Baskaran R and Mohan P M (2012) In vitro antibacterial activity of leaf extracts of Rhizophoramucronata L. against multi drug resistant Vibrio spp. isolated from marine water Lobster's larvae hatcheries Indian Journal of Geo-Marine Sciences 41 218-222

Chellaram C and Praveen M M (2014) Antimicrobial Activity of Marine Bacteria Associated with Oyster from Pulicat Lake 
International Conference on Science Engineering and Management Research (ICSEMR)

Chellaram C, Anand T P, Shailaja N R and Kesavan D (2012) Herbicidal effects of marine animal, Trochus tentorium from Gulf of Mannar, Southeastern India Asian Journal of Animal and Veterinary Advances 7 250-255

Ciavatta M L, Devi P, Carbone M, Mathieu V, Kiss R, Casapullo A and Gavagnin M (2016) Kahalalide F analogues from the mucous secretion of Indian sacoglossanmollusc Elysia ornate Tetrahedron 72 625-631

Dahiya R, Singh S, Sharma A, Chennupati S V and Maharaj S (2016) First total synthesis and biological screening of a proline-rich cyclopeptide from a carribean marine sponge Marine Drugs Dec 14 228. DOI: 10.3390/md14120228

Demunshi Y and Chug A (2009) Patenting trends in marine bioprospecting based pharmaceutical sector Journal of Intellectual Property Rights 14 122-130

Devi P, Rodrigues C, Naik C G and D'Souza L (2012) Isolation and characterization of antibacterial compound from a mangrove-endophytic fungus, Penicillium chrysogenum MTCC 5108 Indian Journal of Microbiology 52 617-623

Dhevagi P, Brundha A, Geetha K, Gobu R, Manju K A A and Poorani E (2017) A preliminary study on the antimicrobial activity of marine actinomycetes Journal of Environmental Biology 38 483-88

Donia M and Hamann M T (2003) Marine natural products and their potential applications as anti-infective agents Lancet Infect Dis 3 338-48

Durai S, Vigneshwari Land Balamurugan K (2013) Caenorhabditis elegans-based in vivo screening of bioactives from marine sponge-associated bacteria against Vibrio alginolyticus Journal of Applied Microbiology 115 1329-1342

Dusane D H, Damare S R, Nancharaiah Y V, Ramaiah N, Venugopalan V P, Kumar A R and Zinjarde S S (2013) Disruption of microbial biofilms by an extracellular protein isolated from epibiotic tropical marine strain of Bacillus licheniformis PLOS One $\mathbf{8}$ e64501

Hemalatha A, Parthiban C, Saranya C, Girija K and Anantharaman P (2015) Evaluation of antioxidant activities and total phenolic contents of different solvent extracts of selected marine diatoms Indian Journal of Geo-Marine Sciences $\mathbf{4 4}$ 1630-1636

Hridya V K, Godson P S and Chandrasekar N (2012) Chromatographic identification of two biologically important triterpenoids from the chloroform extract of Rhizophoramucronata Acta Chromatographica 24 123129

Inbaneson S J and Ravikumar S (2012) In vitro antiplasmodial activity of bacterium RJAUTHB 14 associated with marine sponge Haliclona Grant against Plasmodium falciparum Parasitology Research 110 2255-2262

Jain A, Yadav B K and Chugh A (2015) Marine antimicrobial peptide tachyplesin as an efficient nanocarrier for macromolecule delivery in plant and mammalian cells FEBS Journal 282 732-745

Joy M and Chakraborty K (2017) Previously undescribed antioxidative and anti-inflammatory chromenyls bearing $3 \mathrm{H}$-isochromenone and furanyl-2H-chromenyl skeletons from the venerid clam, Paphiamalabarica Medicinal Chemistry Research 26 1708-1722

Joy M, Chakraborty K and Raola V K (2017) New sterols with anti-inflammatory potentials against cyclooxygenase-2 and 5-lipoxygenase from Paphiamalabarica Natural Product Research 31 1286-1298

Kalimuthu K, Lin S M, Tseng L C, Murugan K and Hwang J S (2014) Bio-efficacy potential of seaweed Gracilaria firma with copepod, Megacyclopsformosanus for the control larvae of dengue vector Aedesaegypti Hydrobiologia 741 113-123

Kathiraven T, Sundaramanickam A, Shanmugam N and Balasubramanian T (2015) Green synthesis of silver nanoparticles using marine algae Caulerparacemosa and their antibacterial activity against some human pathogens Applied Nanoscience 5 499-504

Kaushik N K, Murali T S, Sahal D and Suryanarayanan T S (2014) A search for antiplasmodial metabolites among fungal endophytes of terrestrial and marine plants of southern India Acta Parasitological 59 745-757

Kavita K, Singh V K and Jha B (2014) 24-Branched Delta 5 sterols from Laurenciapapillosared seaweed with antibacterial activity against human pathogenic bacteria Microbiological Research 169301-306

Kumar C S, Gadewal N and Mohammed S M M (2013) Identification of leads from marine seaweeds against human beta-tubulin Letters In Drug Design \& Discovery 10 6774

Kumar M S, Desai D and Pal A K (2012) Immunomodulatory potential of a marine sponge Spongosoriteshali chondrioides (Dendy, 1905) Turkish Journal of Fisheries and Aquatic Sciences 12 63-67

Kumar N S S, Nazeer R A and Jaiganesh R (2012) Wound Healing Properties of Collagen from the Bone of Two Marine Fishes International Journal of Peptide Research and Therapeutics 18 185-192

Kumar P S, Krishna E R, Sujatha P and Kumar B V (2012) Screening and isolation of associated bioactive 
microorganisms from Fasciospongia cavernosa from Visakhapatnam Coast, Bay of Bengal E-Journal of Chemistry 9 2166-2176

Kumaran N S, Bragadeeswaran S, Balasubramanian T and Meenakshi V K (2012) Bioactivity potential of extracts from ascidian Lissoclinum fragile African Journal of Pharmacy and Pharmacology 6 1854-1859

Kyadari M, Fatma T, Azad R and Velpandian T (2013) Evaluation of antiangiogenic and antiproliferative potential of the organic extract of green algae chlorella pyrenoidosa Indian Journal of Pharmacology 45 569-574

Lillsunde K E, Festa C, Adel H, De Marino S, Lombardi V, Tilvi S, Nawrot D A, Zampella A, D'Souza L, D'AuriaM V and Tammela P (2014) Bioactive cembrane derivatives from the Indian Ocean soft coral, Sinulariakavarattiensis Marine Drug 12 4045-4068

Lopez-Abarrategui C, McBeth C, Mandal S M, Sun Z Y J, Heffron G, Alba-Menendez, A, Migliolo L, Reyes-Acosta O, Garcia-Villarino M, Nolasco D O, Falcao R, Cherobim M D, Dias S C, Brandt W, Wessjohann L, Starnbach M, Franco O L and Otero-Gonzalez A J (2015) Cm-p5: an antifungal hydrophilic peptide derived from the coastal mollusc Cenchritismuricatus (Gastropoda: Littorinidae) FASEB Journal 29 3315-3325

Majik M S, Rodrigues C, Mascarenhas S and D'Souza L (2014) Design and synthesis of marine natural product-based $1 \mathrm{H}-$ indole-2,3-dione scaffold as a new antifouling/antibacterial agent against fouling bacteria Bioorganic Chemistry 54 8995

Malve H J (2016) Exploring the ocean for new drug developments: Marine pharmacology Pharm Bioallied Sci 8 83-91

Managamuri U, Vijayalakshmi M, Ganduri V S R K, Rajulapati S B, Bonigala B, Kalyani B S and Poda S (2017) Isolation, identification, optimization, and metabolite profiling of Streptomyces sparsus VSM-30 3 Biotech Jul 7217

Mani C, Thirugnanasambantham K, Sundarapandian S and Poopathi S (2015) Identification and characterization of a novel marine Bacillus cereus VCRC-B540 for mosquito control Biocontrol $6071-79$

Manilal A, Selvin J, Thajuddin N, Sujith S, Panikkar M V N, Idhayadhulla A and Kumar R S (2012) Biopotentials of marine alga, Lobophoravariegata collected from the south Indian littoral Thalassas 28 47-55

Manilal A, Selvin J, Kiran G S, Sujith S, Feby FA S andLipton A P (2013) Micro-algal lethality potentials of marine organisms collected from the Indian littoral Thalassas 29 59-65

Mary M R P, Sugumar G, Kumar M P, Chrisolite B and Meenakshi
V K (2016) Antagonistic effect of bacteria associated with ascidians from Thoothukudicoast Indian Journal of GeoMarine Sciences 45 1208-1217

Mittermeier C G N , da Fonseca G A B and Kent J (2000) Biodiversity hotspots for conservation priorities Nature 403 853-858

Montalvao S, Demirel Z, Devi P, Lombardi V, Hongisto V, Perala M, Hattara J, Imamoglu E, Tilvi S S, Turan G, Dalay M C and Tammela P (2016) Large-scale bioprospecting of cyanobacteria, micro- and macroalgae from the Aegean Sea May 2533 399-406 DOI: 10.1016/j.nbt.2016.02.002

Murti Y and Agarwal T (2010) Marine derived pharmaceuticalsdevelopment of natural health products from marine biodiversity Int J ChemTech Res 2 2198-217

Muthukumar T, Prakash D, Anbarasu K, Kumar B S and Sastry T P (2014) Effect of collagen sponge incorporating Macrotylomauniflorum extract on full-thickness wound healing by down-regulation of matrix metalloproteinases and inflammatory markers RSC Advances 4 64267-64276

Nagarani N and Kumaraguru A K (2012) Investigation of the effect of K-alvarezii on antioxidant enzymes, cell viability and DNA damage in male rats Frontiers in Life Science $\mathbf{6}$ 97-105

Nagarani N, Janaki Devi V, Yokesh Babu M and Kumaraguru A K (2012) Protective effect of Kappaphycusalvarezii (Rhodophyta) extract against DNA damage induced by mercury chloride in marine fish Toxicological and Environmental Chemistry 94 1401-1410

Naine S J and Devi C S (2014) Larvicidal and repellent properties of Streptomyces sp VITJS4 crude extract against Anopheles stephensi, Aedesaegyptii and Culexquinquefasciatus (Diptera: Culicidae) Polish Journal of Microbiology 63 341-348

Pandey S, Sree A, Dash S S, Sethi D P and Chowdhury L (2013) Diversity of marine bacteria producing beta-glucosidase inhibitors Microbial Cell Factories 1235 Accessed at https:/ /doi.org/10.1186/1475-2859-12-35

Pandey S, Sree A, Sethi D P, Kumar C G, Kakollu S, Chowdhury L and Dash S S (2014) A marine sponge associated strain of Bacillus subtilis and other marine bacteria can produce anticholinesterase compounds Microbial Cell Factories 1524

Patra S and Muthuraman M S (2013) Gracilaria edulis extract induces apoptosis and inhibits tumor in Ehrlich Ascites tumor cells in vivo BMC Complementary and Alternative Medicine Nov 2513331 DOI 10.1186/1472-6882-13-331

Pawar R, Mohandass C, Dastager S G, Kolekar Y M and Malwankar R (2016) Antioxidative Metabolites 
Synthesized by Marine Pigmented Vibrio sp and Its Protection on Oxidative Deterioration of Membrane Lipids Applied Biochemistry and Biotechnology 179 155-167

Pawar R, Mohandass C, Sivaperumal E, Sabu E, Rajasabapathy $\mathrm{R}$ and Jagtap $\mathrm{T}$ (2015) Epiphytic marine pigmented bacteria: A prospective source of natural antioxidants Brazilian Journal of Microbiology 46 29-39

Poopathi S, Mani C, Thirugnanasambantham K, Praba V L, Ahangar N A and Balagangadharan K (2014) Identification and characterization of a novel marine Bacillus cereus for mosquito control Parasitological Research 113 323-332

Poopathi S, Ahangar N A, Thirugnanasambantham K, PrabaV L and Mani C (2014) Isolation and characterisation of a new mosquitocidal bacterium strain of Enterobacter cloacae VCRC-B519 from marine soil Biocontrol Science and Technology 24 158-169

Prabhu V V and Guruvayoorappan C (2013) Inhibition of metastatic lung cancer in C57BL/6 mice by marine mangrove Rhizophoraapiculata Asian Pacific Journal of Cancer Prevention 14 1833-1840

Prabhu V V and Guruvayoorappan C (2012) Anti-inflammatory and anti-tumor activity of the marine mangrove Rhizophoraapiculata Journal of Immunotoxicology 9341 352

Rajendran P, Subramani PA and Michael D (2016) Polysaccharides from marine macroalga, Padinagymnospora improve the nonspecific and specific immune responses of Cyprinuscarpio and protect it from different pathogens Fish \& Shellfish Immunology 58 220-228

Rajesh Kumar R K, Vennila R, Karthikeyan S, Prasad N R, Arumugam M, Velpandian $\mathrm{T}$ and Balasubramaniam $\mathrm{T}$ (2015) Antiproliferative activity of marine stingray Dasyatissephen venom on human cervical carcinoma cell line Journal of venomous animals and toxins including tropical diseases [online] Volume 21Epub Nov 102015 DOI 10.1186/s40409-015-0036-5

Ravindran C, Varatharajan G R, Rajasabapathy R andSreepada R A(2016) Antibacterial activity of marine bacillus substances against Vibrio cholerae and Staphylococcus aureus and in vivo evaluation using embryonic zebrafish test system Indian Journal of Pharmaceutical Sciences 78 417-422

Rethinam S, Nivedita P, Hemalatha T, Vedakumari S W and Sastry T P (2016) A possible wound dressing material from marine food waste International Journal of Artificial Organs 39 509-517

Sahayaraj K, Rajesh S and Rathi J M (2012) Silver nanoparticles biosynthesis using marine alga Padinapavonica (Linn.) and it's microbicidal activity Digest Journal of
Nanomaterials and Biostructures 7 1557-1567

Saritha Kumari C H and Kurup G M (2013) Alginic acid isolated from Sargassumwightii exhibits anti-inflammatory potential on type II collagen induced arthritis in experimental animals International Immunopharmacology 17 1108-1115

Sathiyanarayanan G, Gandhimathi R, Sabarathnam B, Kiran G S and Selvin J (2014) Optimization and production of pyrrolidone antimicrobial agent from marine spongeassociated Streptomyces spp. MAPS15 Bioprocess and Biosystems Engineering 37 561-573

Senthilkumar P and Sudha S (2012) Antioxidant and antibacterial properties of methanolic extract of green seaweed Chaetomorphalinum from Gulf of Mannar: Southeast Coast of India Jundishapur Journal of Microbiology 5 411-415

Sharma N, Pinnaka A K, Raje M, Fnu A, Bhattacharyya M S and Choudhury A R (2012) Exploitation of marine bacteria for production of gold nanoparticles Microbial Cell Factories Published on 20 June 2012 Accessed at https://doi.org/ 10.1186/1475-2859-11-86

Skariyachan S, Rao A G, Patil M R, Saikia B, Bharadwaj K N V and Rao G S J (2014) Antimicrobial potential of metabolites extracted from bacterial symbionts associated with marine sponges in coastal area of Gulf of Mannar Biosphere, India Letters in Applied Microbiology 58 231-241

Smitha S and Bhat S G (2013) Thermostable Bacteriocin BL8 from Bacillus licheniformis isolated from marine sediment Journal of Applied Microbiology 114 688-694

Sugathan S, Manilal A, Selvin J, Idhayadhulla A, Kumar R S and Panikkar M V N (2012) Evaluating the antagonistic potential of seaweed-associated marine bacteria collected from the southwest coast of India Asian Journal of Animal and Veterinary Advances 7 578-587

Syad A N and Kasi PD (2014) Assessment of mutagenic effect of G. acerosa and $S$. wightii in S. typhimurium (TA 98, TA 100 , and TA 1538 strains) and evaluation of their cytotoxic and genotoxic effect in human mononuclear cells: A nonclinical study Biomed Research International 2014 Article ID 3139428 pages DOI:10.1155/2014/313942

Thakur N L, Thakur A N and Muller W E G (2005) Marine natural products in drug discovery Natural Product Radiance 4 471-7

Thenmozhi M, Gopal J V, Kannabiran K, Rajakumar G, Velayutham K and Rahuman A A (2013) Eco-friendly approach using marine actinobacteria and its compounds to control ticks and mosquitoes Parasitology Research 112 719-729

Unnikrishnan P S, Suthindhiran K and Jayasri M A (2015) Alpha- 
amylase inhibition and antioxidant activity of marine green algae and its possible role in diabetes management Pharmacognosy Magazine 11 511-515

Velho-Pereira S and Furtado I (2012) Antibacterial activity of halophilic bacterial bionts from marine invertebrates of Mandapam-India Indian Journal of Pharmaceutical Sciences $\mathbf{7 4}$ 331-338

Vijayakumar R, Panneerselvam K, Muthukumar C, Thajuddin N, Panneerselvam A and Saravanamuthu R (2017)
Optimization of antimicrobial production by a marine actinomycete Streptomyces afghaniensis VPTS3-1 isolated from Palk Strait, East Coast of India Indian Journal of Microbiology 52 230-239

Visamsetti A, Ramachandran S S and Kandasamy D (2016) Penicillium chrysogenum DSOA associated with marine sponge (Tedaniahelans) exhibit antimycobacterial activity Microbiological Research 185 55-56. 